\title{
WP 20_08
}

Thanasis Stengos

University of Guelph, Canada

and

The Rimini Centre for Economic Analysis, Italy

Constantina Kottaridi

University of Peloponnese, Greece

\section{"Foreign Direct Investment, Human Capital and Nonlinearities in Economic Growth"}

Copyright belongs to the author. Small sections of the text, not exceeding three paragraphs, can be used provided proper acknowledgement is given.

The Rimini Centre for Economic Analysis (RCEA) was established in March 2007. RCEA is a private, non-profit organization dedicated to independent research in Applied and Theoretical Economics and related fields. RCEA organizes seminars and workshops, sponsors a general interest journal The Review of Economic Analysis, and organizes a biennial conference: Small Open Economies in the Globalized World (SOEGW). Scientific work contributed by the RCEA Scholars is published in the RCEA Working Papers series.

The views expressed in this paper are those of the authors. No responsibility for them should be attributed to the Rimini Centre for Economic Analysis. 


\title{
FOREIGN DIRECT INVESTMENT, HUMAN CAPITAL AND \\ NONLINEARITIES IN ECONOMIC GROWTH
}

\author{
CONSTANTINA KOTTARIDI \\ University of Peloponnese, School of Management and Economics, Department of Economics
}

THANASIS STENGOS

University of Guelph, Department of Economics

January, 2008

\begin{abstract}
This paper examines the effect of FDI on the process of economic growth by allowing the impact to differ both across each country and also across each time period. We apply non-parametric techniques taking into account the previously documented nonlinear effects of initial income and human capital on economic growth. We use a wide range of countries, both developed and developing in order to be able to distinguish potential differential effects between the two groups. Our findings suggest that FDI inflows have a moderately nonlinear effect on growth and that the human capital nonlinear effect in the presence of FDI inflows is similar to the one found elsewhere in the relevant literature.
\end{abstract}

Keywords: cross country growth regressions, FDI, human capital, semi-parametric additive model JEL Classification: $\mathrm{O} 47$ 


\section{INTRODUCTION}

The role of Foreign Direct Investment (FDI) in the growth process has for long raised intense debates. Although this debate has provided rich insights into the relationship between FDI and growth, theory provides contradicting predictions about this relationship. FDI is considered a vehicle through which new ideas, advanced techniques, technology and skills are transferred across borders hence provide substantial spillover effects. In this sense, and within the framework of new growth theories that stress the effect of technological progress on long-run growth rates, FDI may be considered an important factor boosting growth. There is a body of literature that analyses the effect of FDI on growth and another concentrating on knowledge spillovers to domestic firms ${ }^{1}$. Empirical evidence seems also contradictory: firm-level studies of particular countries often conclude that FDI is not beneficial to growth and also fail to obtain positive spillover effects to domestic enterprises. On the other hand, country-wide studies examining the effect of FDI inflows in the growth process of countries usually provide positive results, especially in specific environments.

The above are particularly of interest for developing and least developed countries (LDC), which basically lack the necessary background in terms of education, infrastructure, economic and political stability in order to be able to innovate and generate new discoveries and designs and in this vein, FDI and its agents, Multinationals Corporations (MNCs) may conceivably help technological advancement domestically. On the other side of the coin, developing countries and LDCs lack the necessary environment, hence they are not able to reap the benefits associated with FDI and as a consequence they are only used as platforms for MNCs

\footnotetext{
${ }^{1}$ For recent surveys please refer to de Mello, 1997; Kumar and Siddharthan,, 1997 and Saggi, 2000)
} 
to promote their own benefit by establishing rent-seeking activities. Moreover, The presence of MNCs may affect domestic firms adversely given the market power of their proprietary assets such as technology, superior brand names and aggressive marketing techniques and as a result, FDI may crowd-out domestic investment.

The contribution of this paper is threefold: First, it provides a systematic investigation of the FDI-growth nexus by employing a general econometric framework that allows the effect of FDI on economic growth to differ both intra and inter-temporally by means of recently-developed non-parametric estimation techniques. Whilst there are a number of studies that bring up the issue of nonlinear effects of FDI on growth, these are imposing specific restrictions as to the nonlinearity on the grounds of human capital, level of development, financial development and degree of openness to trade, by simply incorporating interaction terms in a linear regression framework, or splitting the sample of countries into groups according to the above. Instead, we impose no prior restriction on the potential nonlinearity of FDI on economic growth by resorting to non-parametric techniques, outstripping thus existing criticism on the parametric econometric specification. Second, we would like to check whether the nonlinear effects of human capital on growth established recently in the literature still holds in the presence of FDI inflows. Third, while the vast majority of existing related parametric FDI literature stressing nonlinear effects of FDI on growth on the basis of the human capital scale of countries, takes for granted that human capital itself exerts a linear positive impact on economic growth, we drop this assumption and allow for possibly non-linear human capital effects. Hence, we test for joint effects and interaction of FDI and human capital on economic growth allowing for intra and inter temporal impacts of both on economic growth. We use a wide range of countries, both developed and developing 
in order to be able to distinguish potential differential effects between the two groups. We reach several conclusions. First, we reestablish that initial income and human capital have a nonlinear effect on economic growth. Second, the relationship between FDI and economic growth is quite complex. The effect of FDI on economic growth differs according to a country's receipts of FDI inflows irrespective of whether they regard developed or developing countries. Third, contrary to the vast majority of previous studies interacting FDI and human capital to jointly assess their impact on economic growth we do not obtain a robust joint effect. Hence our results give support to the two very recent studies that contradict the positive interaction result (Durham, 2004; Carcovic and Levine, 2002). The results may have interesting policy implications. On the one hand, they give credit to policies encouraging rapid expansion of tax incentives, infrastructure subsidies, import duty exceptions and other measures aiming at attracting more FDI as they indicate an overall positive effect. On the other hand, it appears that there are threshold effects of FDI on the output expansion of countries and these thresholds do not rely on their human capital base as this is accounted for by the total mean years of schooling. The nonlinearity appearing in the relationship indicates that FDI affects growth in a different way across countries. Furthermore, this differential impact does not necessarily hold on the basis of the countries' human capital absorptive capacity. Rather, this study suggests that the relationship is much more complex than that since the human capital itself exerts also a nonlinear effect on economic growth. This may signal the need for a more specialized analysis and policy design within each country since i) FDI may take place in very different sectors/industries among countries on the one hand and on the other hand even if it is in the same sectors/industries it might exhibit different productivities ii) though there appears to be a consensus that it is imperative for a 
country to have a certain level of absorptive capacity in order to be able to reap the benefits associated with spillover effects, it emerges that this absorptive capacity is likely to depend on a synthesis of necessary economic, financial, political and institutional conditions and not solely on a particular aspect (like the human capital) iii) the evidence is also consistent with Durlauf ad Johnson (1995) pointing to a model in which countries pass through distinct phases of development towards a unique steady state. That is, at a given time interval, countries display differences in their growth characteristics in their transition to a high growth position (Galor, 2005) and this is reflected in the observed nonlinearities in the data. As a consequence to the above, policy design with regard to FDI should rather be country-specific based on the peculiar conditions prevailing internally than follow practices implemented elsewhere or rely on general conclusions drawn by research or practice.

The paper is organized as follows: the next section discusses the relevant evidence so far with regards to the role of FDI on growth and human capital and growth. Section 3 discusses the methodology and data sources, section 4 then lays out empirical findings and finally section 5 concludes.

\section{LITERATURE REVIEW}

As discussed above, firm level studies usually fail to reach positive growth or positive spillover effects into the host nation. Among those we find the influential study of Aitken and Harisson (1999) for Venezuela, Haddad and Harisson (1993) for a number of developing countries, Kokko (1994) for Mexico regarding industries where foreign affiliates exhibit higher productivity and a larger market share than the domestic firms. In other industries though, she find positive effects between foreign 
presence and local productivity. Kokko et al. (1996) for Uruguay and Kathuria (2001) for India conclude accordingly. An affirmative positive affect is suggested in Blomstrom (1986) for Mexico.

The literature is much richer in the macroeconomic context. Positive effects of FDI on growth or productivity spillovers are attributed to Findlay (1978), De Gregorio (1992) for twelve Latin American countries, Blomstrom, Lipsey and Sejan (1992) for 78 developing countries, Blomstrom et al. (1994) for a sample of both developed and developing countries ${ }^{2}$, Sanchez-Robles (1998) for Latin America, Baldwin et al. (1999) for 9 OECD countries, Zhang (2001) for the majority of EastAsian economies and Latin America and Bende-Nabende and Ford (1998) for Taiwan.

Another line of research points to differential impact between developed and developing countries, for example, De Mello (1999) for 15 OECD and 17 non-OECD countries for the period 1970-1990 and Xu (2000) for US FDI in 40 countries for the period 1966-1994

Finally, there is an array of works that stress the positive role of FDI conditioned on adequate local factors ${ }^{3}$, especially human capital. Borenzstein et al. (1998) in their study of 69 developing economies for 1970-1989 concluded that the effect of FDI is dependent on the human capital stock. Bengoa and Sanchez-Robles (2003) reached the same conclusion for Latin America ${ }^{4}$, Kottaridi (2005) examined the FDI-growth nexus across the EU core and periphery countries for 1980-2001 and found out that

\footnotetext{
${ }^{2}$ However, when they split their sample of developing countries into two groups based on their level of income per capita they found that FDI was not statistically significant for lower income developing countries although it remained positive.

${ }^{3}$ Balasubramanyam et al. (1996) examined a number of developing countries for 1970-1985 and concluded that FDI is enhancing for those that follow an export oriented trade policy regime, Alfaro et al. (2003) found growth enhancing effects of FDI in economies with sufficiently developed financial markets.

${ }^{4}$ Also based on economic stability and liberalized financial markets.
} 
FDI is beneficial for core countries with adequate stocks of human capital but failed to obtain a statistically significant result for the periphery although the coefficient was with the correct (positive) sign.

All relevant studies discussed above regarding the growth enhancing role of FDI based on local "absorptive capacity", impose restrictions as to the type of nonlinearity and are confined to parametric techniques by simply incorporating interaction terms in their regressions or by splitting the sample of countries into groups to test such a hypothesis.

Very recently, two studies emerged to contradict the majority of macroeconomic evidence of a beneficial effect. Carcovic and Levine (2002) criticized existing empirical studies as not fully controlling for simultaneity bias, country-specific effects and the use of lagged dependent variables in their growth regressions. They use GMM and they assess the FDI-growth relationship for 72 countries covering the period 1960-1995. Their findings suggest that FDI does not exert an independent influence on economic growth. Durham (2004) also examined 80 countries between 1979 and 1998 using extreme bound analysis and failed to achieve a robust positive effect.

Though a large portion of studies stresses the particular role of human capital for FDI to be beneficial to host countries, the contribution of human capital to growth is controversial in its own. Whereas at the micro level there is consistent evidence that education raises incomes significantly ${ }^{5}$, evidence at the micro level has been mixed. Studies such as Barro (1991), Bils and Klenow (2000), Mankiw et al. (1992) and others use enrollment rates for primary and secondary education and point toward a positive and significant effect. Benhabib and Spiegel (1994), Kyriacou (1991), Lau et al. (1991) and Pritchet (2001) on the other hand find an insignificant or even negative

\footnotetext{
${ }^{5}$ Commonly referred to as Mincerian wage regressions
} 
result for the stock of human capital, i.e. the total means years of schooling. Some authors (Barro, 1998; Barro and Sala-i-Martin, 1995) incorporate differentiated measures of human capital not only by level of education but also by gender. Regarding the time dimension of growth, it is found that as the frequency of changes over which growth rates are calculated increases there is less evidence of a positive effect of human capital accumulation on growth (Krueger and Lindahl, 2000; and Islam, 1995).

The vast majority of the studies to the empirics of economic growth have assumed that human capital exerts the same effect on economic growth both across countries and across time and have assumed a $(\log )$ linear relationship. Motivated by recent theories emphasizing threshold externalities (Azariadis and Drazen, 1990) several researchers have questioned this assumption. Durlauf and Johnson (1995) and Masanjala and Papageorgiou (2004) use the regression tree and the threshold regression methodology to show the existence of multiple regimes.

Liu and Stengos (1999) allow for two nonlinear components, one for the initial GDP level and the other for the secondary enrollment rate. Kalaitzidakis et al. (2001) use semi-parametric techniques and find that there are substantial non-linearities in the growth-human capital nexus. Kourtellos (2003) also uses a semiparametric smooth coefficient model to study a local generalization of the Solow model in the spirit of Durlauf et al. (2001). More recently, Mamuneas, Savvides and Stengos (2006) estimate a general model of the economic growth process for 51 countries during 1971-1987 by allowing the contribution of both traditional inputs and human capital to vary across both countries and time and find that the average output elasticity of human capital varies substantially across countries and above that in some cases the estimate is negligible. 
The aim of our study is to detect potential nonlinearities in the FDI-economic growth relationship in the presence of human capital as we attempt to check whether the nonlinearities of the human capital effect found in the literature still holds in the presence of FDI. In addition we also try to assess the joint effect of FDI and human capital given that the majority of the related literature points to a positive sign with the exception of two influential recent papers, though they employ parametric techniques, claiming that such impact does not exist (Durham, 2004; Carcovic and Levine, 2002)

\section{METHODOLOGY, DATA AND SOURCES}

We follow an extended Solow type model as in Mankiw et al. (1992), whereby investment is divided between its domestic and its foreign direct component.

We assume a production function of the form $Y_{t}=K_{d t}^{\alpha} K_{f t}^{\beta} H_{t}^{\gamma}\left(\mathrm{A}_{t} L_{t}\right)^{1-\alpha-\beta-\gamma}$, where $\mathrm{Y}$, $K_{d}, K_{f}, H$ and $L$ represent total output, domestic physical capital stock, foreign physical capital stock, human capital stock and labor respectively and $\mathrm{A}$ is a technological parameter. Technology is assumed to grow exponentially at the rate $g$, or $A_{t}=A_{0} e^{g t}$. Along the lines of Mankiw et al. (1992) we define $k_{d}$ as the stock of domestic capital per effective unit of labor, $k_{d}=K_{d} / A L$ and $k_{f}$ as the stock of foreign capital per effective labor, $k_{f}=K_{f} / A L$, and $y$ as the level of output per effective unit of labor, $y=Y / A L$.

Hence, following an extended Solow type model and in common with most recent contributions we employ panel data estimations of the unrestricted model suggested by Mankiw et al. adding foreign direct investment in the right hand side. 


$$
y_{i t}=\alpha_{0}+\alpha_{1} \ln I_{i t}^{d} / Y+\alpha_{2} \ln \left(n_{i t}\right)+\alpha_{3} \ln x_{i t}+\alpha_{4} \ln I_{i t}^{f} / Y+a_{5} \ln h_{i t}+\varepsilon_{i t}(1)^{6}
$$

where $y_{i t}$ refers to the growth rate of income per capita during each period, $x_{i t}$ is per capita income at the beginning of each period, $I^{d} / Y$ is the domestic investment taking place in the economy, $I^{f} / Y$ foreign direct investment and $h_{i t}$ is human capital.

Whilst Mankiw et al. (1992) used the secondary enrollment rate to measure human capital and Barro and Sala-i-Martin (1995) used the primary as well as secondary enrollment ratios, recent research on human capital has focused on stock measures of human capital as more appropriate. We follow here this recent trend and measure human capital as total mean years of schooling. The data were obtained and updated from Vikram and Dhareshwar (1993). For a full description of their methodology see Vikram, Swanson and Dubey (1995). The data cover the period 1950 to 1990 therefore we use extrapolation to update the human capital stock up to 2004. We also took into consideration the Barro and Lee (2001) human capital stock, however, we cannot directly use their data since their data are calculated in 5-year intervals. Foreign direct investment is obtained by United Nations Cooperation on Trade and Development (UNTAD). FDI inflows comprise capital provided (either directly or through other related enterprises) by a foreign direct investor to a FDI enterprise. FDI includes the three following components: equity capital, reinvested earnings and intra-company loans. Equity capital is the foreign direct investor's purchase of shares of an enterprise in a country other than that of its residence. Reinvested earnings comprise the direct investor's share (in proportion to direct equity participation) of earnings not distributed as dividends by affiliates or earnings not

\footnotetext{
${ }^{6}$ For simplicity we assume that $\mathrm{g}$ and $\delta$ (the depreciation rate stemming out of the solution) are equal to zero.
} 
remitted to the direct investor. Such retained profits by affiliates are reinvested. Intracompany loans or intra-company debt transactions refer to short- or long-term borrowing and lending of funds between direct investors (parent enterprises) and affiliate enterprises. Data on FDI flows are presented on net bases (capital transactions' credits less debits between direct investors and their foreign affiliates). Net decreases in assets or net increases in liabilities are recorded as credits (with a positive sign), while net increases in assets or net decreases in liabilities are recorded as debits (with a negative sign). Hence, FDI flows with a negative sign indicate that at least one of the three components of FDI is negative and not offset by positive amounts of the remaining components. These are called reverse investment or disinvestment. $^{7}$ All other data on we have used regarding GDP per capita, GDP per capita growth, gross fixed capital formation measuring domestic investment are in constant 2000 US\$ and are obtained from the World Development Indicators (WDI) of the World Bank. ${ }^{8}$

The sample we are testing covers a wide range of developed and developing countries for the period 1970 to 2004. In particular we incorporate twenty-five OECD countries and twenty non-OECD countries from all over the world, representing all regions. The selection of developing countries was based on the availability of the data especially with regards to the human capital variable. A full list of the countries and the regions they belong to may be found in Appendix A.

\footnotetext{
${ }^{7}$ For more detailed information please refer to the UNCTAD World Investment Report 2005: Transnational Corporations and the Internationalization of R\&D.

${ }^{8}$ Nevertheless, we have used other data sources for these variables for robustness purposes. We have also experimented with the corresponding variables from the Penn World Tables 6.2 where the variables are given in 2000 PPP US\$. However, results were similar.
} 


\section{ECONOMETRIC ESTIMATION}

Parametric estimates assume a unique response coefficient for human capital and FDI in growth regressions. Recent work, however, has indicated that this assumption is not warranted. Azariadis and Drazen (1990), Durlauf and Johnson (1995) and Murphy et al. (1989) point to the possibility of threshold effects in the growth process, the former focusing on thresholds in human capital. Alternatively, the growth experience is a nonlinear function of human capital. While non linearities in the convergence process have been extensively discussed in the literature ${ }^{9}$, remarkably little has appeared in connection with human capital and nil to the best of our knowledge regarding the effect if FDI on economic growth.

We hereby use a semiparametric partially linear regression (PLR) specification of the growth regression function. In contrast to a standard linear parametric formulation, a semiparametric PLR specification is an adequate representation for the data. Using a particular version of the PLR models that allows for additive semiparametric components, we obtain graphical representations of the nonparametric components: initial GDP per capita, FDI and human capital. These graphs can shed light into nonlinearities in these variables and can be used as a guide to a more suitable parametric specification.

The semiparametric PLR specification of the model in (1) can be written as follows:

$$
y_{i t}=X_{i t}^{\mathrm{T}} \gamma+g\left(Z_{i t}\right)+u_{i t}(2)
$$

where $X_{i t}$ is a variable of dimension $\mathrm{q}, \gamma$ is a $\mathrm{q} \times 1$ vector of unknown parameters, $Z_{i t}$ is a continuous variable of dimension $\mathrm{p}$ and $g(\cdot)$ is an unknown function. In the

\footnotetext{
${ }^{9}$ See for example Quah (1996).
} 
context of equation (2) $X_{i t}=\left\{D_{j}, I_{i t}^{k} / Y, n_{i t}\right\}$ and $Z_{i t}=Z_{1 i t}, \ldots, Z_{p i t}$ where $Z_{1 i t}$ refers to initial income $x_{i t}, Z_{2 i t}$ refers to FDI and $Z_{3 i t}$ to human capital. Robinson (1988) provided a way of obtaining a $\sqrt{n}$-consistent estimator of the parameter vector $\gamma$ By concentrating out the influence of the nuisance variables, the Zs. This is accomplished by conditioning them through kernel methods and estimating the conditional expectations $E\left(y_{i t} / Z_{i t}\right)$ and $E\left(X_{i t} / Z_{i t}\right)$. In the second stage of a two-step estimation procedure, the kernel estimates of $E\left(y_{i t} / Z_{i t}\right)$ and $E\left(X_{i t} / Z_{i t}\right)$ are used to estimate the parameter vector $\gamma$.

Such an approach, although very useful if one were interested solely in the parameter vector $\gamma$ conceals the influence of the individual $\mathrm{Zs}$ in the regression function. For the question at hand, a more useful approach is to try to uncover the shapes of the individual components of $Z_{i t}$, i.e., $x_{i t}, f_{i t}$ and $h_{i t}$. In order to accomplish this, we have to impose more structure on equation (2) by assuming an additive structure on the unknown components. In other words, the regression model can now be written as:

$$
y_{i t}=\alpha+\mathrm{X}_{i t}^{T} \gamma+\sum_{s-1}^{p} g_{s}\left(Z_{i t}\right)+u_{i t}
$$

Linton and Nielsen (1995), Fan, Hardle and Mammen (1998) and Fan and Li (2003) use marginal integration to estimate the components of the additive semiparametric PLR model in equation (3).

\section{EMPIRICAL RESULTS}

The parametric estimates of the growth regression are in Table 1 . We have tried to split the sample between OECD and non-OECD countries in order to detect possible 
differentiation. We have also split the sample among countries classified by the World Bank as high income, middle income and low income ${ }^{10}$. It is noteworthy that coefficients of regions are quite different under the alternative specifications. That is, whilst with the shares of domestic and foreign investment most of them are positive and significant, they turn out negative and significant at least some of them like Africa, Latin America and Oceania. Three general conclusions could be drawn. First, the coefficient estimates for initial GDP per capita, investment, and population growth are of the anticipated sigh and significance and are robust to the alternative subsamples. Second, estimates of FDI turn out to be positive and statistically significant except for the middle and low-income sub-samples. Third, the estimates for human capital follow the pattern of FDI and are positive and significant except for the middle and low-income countries ${ }^{11}$. Note that in the specifications we also include a time trend as a means of capturing business cycle effects ${ }^{12}$. Our parametric results thus, give definitive results related to FDI and human capital and specifically they point towards positive and significant effects. We have also included interaction terms between FDI and human capital according to arguments that FDI needs a threshold of 'absorptive capacity' in terms of human capital in order to be beneficial. Nevertheless, results are in contrast to the majority of previous studies but in line with the two recent parametric contributions (Durham, 2004; Carcovic and Levine, 2001); in some cases the interaction term emerges significantly negative, in others positive but insignificant and there are also cases that FDI or human capital alone turn negative

\footnotetext{
${ }^{10} \mathrm{We}$ have also separated the middle-income countries between those of upper-middle income and lower-middle income. We then have grouped upper middle income with high income and lower-middle income with low income.

${ }^{11}$ We have also estimated the respective models with lagged values of private investment and FDI to account for possible endogeneity of the variables - these two variables loose their significance in some cases whilst the human capital variable remains the same.

${ }^{12}$ We also experimented with powers of the time trend but these turned out to be insignificant
} 
and significant. In this regard, it is really impossible to detect such nonlinearities of FDI.

Table 1. LSDV regressions. Dependent variable: GDP per capita growth; white heteroskedastic standard errors in parentheses; trend included

\begin{tabular}{|c|c|c|c|c|c|c|}
\hline & $\begin{array}{l}(1) \\
\text { ALL }\end{array}$ & $\begin{array}{c}(2) \\
\text { OECD }\end{array}$ & $\begin{array}{c}\text { (3) } \\
\text { non-OECD }\end{array}$ & $\begin{array}{c}\text { (4) } \\
\text { High-Income }\end{array}$ & $\begin{array}{c}(5) \\
\text { Middle- } \\
\text { Income }\end{array}$ & $\begin{array}{c}\text { (6) } \\
\text { Low-Income }\end{array}$ \\
\hline$x$ & $\begin{array}{c}-1.022 * * * \\
(0.148)\end{array}$ & $\begin{array}{c}-1.931)^{* * *} \\
(0.372)\end{array}$ & $\begin{array}{c}-1.186^{* * *} \\
(0.355)\end{array}$ & $\begin{array}{c}-2.049 * * * \\
(0.26)\end{array}$ & $\begin{array}{c}-1.245^{* * *} \\
(0.349)\end{array}$ & $\begin{array}{l}-2.891 \\
(2.08)\end{array}$ \\
\hline$n$ & $\begin{array}{l}-0.317 \\
(0.253)\end{array}$ & $\begin{array}{c}-0.231 \\
(-0.601)\end{array}$ & $\begin{array}{c}-1.624 * * \\
(0.825)\end{array}$ & $\begin{array}{c}-0.11 \\
(-0.407)\end{array}$ & $\begin{array}{c}-3.232 * * * \\
(0.853)\end{array}$ & $\begin{array}{l}3.818 \\
(2.36)\end{array}$ \\
\hline$I_{d} / Y$ & $\begin{array}{l}3.36^{* * *} \\
(0.319)\end{array}$ & $\begin{array}{c}2.988^{* * *} \\
(0.62)\end{array}$ & $\begin{array}{c}3.88^{* * *} \\
(0.669)\end{array}$ & $\begin{array}{c}1.902 * * * \\
(0.534)\end{array}$ & $\begin{array}{c}4.635^{* * * * *} \\
(0.837)\end{array}$ & $\begin{array}{c}4.167^{* * *} \\
(1.35)\end{array}$ \\
\hline$I_{f} / Y$ & $\begin{array}{l}2.32 * * * \\
(0.394)\end{array}$ & $\begin{array}{c}1.382 * * \\
(0.59)\end{array}$ & $\begin{array}{c}2.794 * * * \\
(0.264)\end{array}$ & $\begin{array}{c}2.012 * * * \\
(0.579)\end{array}$ & $\begin{array}{c}2.547 \\
(0.365)\end{array}$ & $\begin{array}{l}0.595 \\
(5.45)\end{array}$ \\
\hline$h$ & $\begin{array}{c}2.207 * * * \\
(0.364)\end{array}$ & $\begin{array}{c}3.402 * * * \\
(0.96)\end{array}$ & $\begin{array}{c}2.282 * * * \\
(0.584)\end{array}$ & $\begin{array}{c}2.558 * * * \\
(0.692)\end{array}$ & $\begin{array}{l}0.937 \\
(1.15)\end{array}$ & $\begin{array}{l}0.038 \\
(1.79)\end{array}$ \\
\hline Africa & $\begin{array}{c}-9.065^{* * *} \\
(1.667)\end{array}$ & & $\begin{array}{c}-9.36^{* * *} \\
(2.42)\end{array}$ & & $\begin{array}{l}-6.47 * * \\
(2.733)\end{array}$ & $\begin{array}{l}-3.854 \\
(21.65)\end{array}$ \\
\hline America & $\begin{array}{c}-7.783^{* * *} \\
(1.601)\end{array}$ & $\begin{array}{l}1.615) \\
(3.17)\end{array}$ & & $\begin{array}{l}6.188^{*} \\
(3.33)\end{array}$ & & \\
\hline Asia & $\begin{array}{c}-7.948^{* * *} \\
(1.55)\end{array}$ & $\begin{array}{c}1.273 \\
(3.315)\end{array}$ & $\begin{array}{c}-8.24 * * * \\
(2.16)\end{array}$ & $\begin{array}{l}6.60^{*} \\
(3.44)\end{array}$ & $\begin{array}{c}-5.582 * * \\
(2.57)\end{array}$ & $\begin{array}{l}-1.318 \\
(20.81)\end{array}$ \\
\hline$E U$ & $\begin{array}{c}-8.224 * * * \\
(1.602)\end{array}$ & $\begin{array}{c}1.316 \\
(3.104)\end{array}$ & & $\begin{array}{l}5.89 * \\
(3.36)\end{array}$ & & \\
\hline Lat.Am & $\begin{array}{c}-9.32 * * * \\
(1.468)\end{array}$ & $\begin{array}{l}0.461 \\
(2.98)\end{array}$ & $\begin{array}{c}-9.74 * * * \\
(2.311)\end{array}$ & & $\begin{array}{c}-6.47 * * \\
(2.67)\end{array}$ & \\
\hline Oceania & $\begin{array}{c}-8.899^{* * *} \\
(1.63)\end{array}$ & $\begin{array}{c}0.389 \\
(3.159)\end{array}$ & & $\begin{array}{c}4.75 \\
(3.26)\end{array}$ & & \\
\hline Other-Eur & $\begin{array}{c}-7.672 * * * \\
(1.717)\end{array}$ & $\begin{array}{c}2.236 \\
3.36\end{array}$ & & $\begin{array}{l}6.97 * * \\
(3.46)\end{array}$ & & \\
\hline $\mathrm{T}$ & $\begin{array}{l}-0.047^{*} \\
(0.017)\end{array}$ & $\begin{array}{l}-0.029 \\
(0.029)\end{array}$ & $\begin{array}{c}-0.061 * \\
(0.03)\end{array}$ & $\begin{array}{l}-0.026 \\
(0.02)\end{array}$ & $\begin{array}{l}-0.081 * \\
(0.057)\end{array}$ & $\begin{array}{l}0.162 \\
(1.43)\end{array}$ \\
\hline Obs & 1481 & 803 & 633 & 794 & 536 & 134 \\
\hline $\begin{array}{l}\text { R-squared } \\
\text { Adjusted R- }\end{array}$ & 0.2304 & 0.227 & 0.3957 & 0.195 & 0.4213 & 0.292 \\
\hline $\begin{array}{l}\text { squared } \\
\text { S.E. of } \\
\text { regression }\end{array}$ & 0.2241 & 4.321 & 0.387 & 0.1847 & 0.4114 & 0.253 \\
\hline F-statistic & $36.624 * * *$ & $19.37 * * *$ & $45.34 * * *$ & $18.97 * * *$ & $42.56 * * *$ & $7.448 * * *$ \\
\hline
\end{tabular}

As indicated above though, parametric estimates assume a unique response coefficient for FDI and human capital in growth regressions. We proceed to test the parametric specifications that are presented in table 1 . We use a recent linearity test 
proposed by $\mathrm{Li}$ and Wang (1998), which is a bootstrap version of the test for functional form of Zheng (1996). In all cases the test statistic rejected the null hypothesis of the null parametric specification strongly with zero p-values. Following recent work we proceeded in the estimation of a semiparametric PLR specification that allows for additive semiparametric components, and we obtain graphical representations of the nonparametric components: initial GDP per capita, FDI and human capital. To tackle possible endogeneity issues between FDI and growth as well between human capital and growth we use lagged values of FDI and human capital instruments. The results are quite similar with and without the lagged values. Following Fan and $\mathrm{Li}$ (1996) we also tested the partially additive semiparametric specification for the model that applies to the whole sample against a more general nonparametric model that would allow for a general nonparametric regression function under the alternative. We failed to reject the null of the semiparametric model with a p-value of 0.35 .

Our semiparemetric results of the PLR model are presented in Figures 1 to 3. Figure 1 shows a representative semiparametric fit for initial income. The horizontal axis shows the initial income per capita and the vertical axis the growth rate in standardized form. To highlight the differences between the semiparametric and the linear estimates in this, as well as all subsequent graphs, we plot the linear benchmark. 


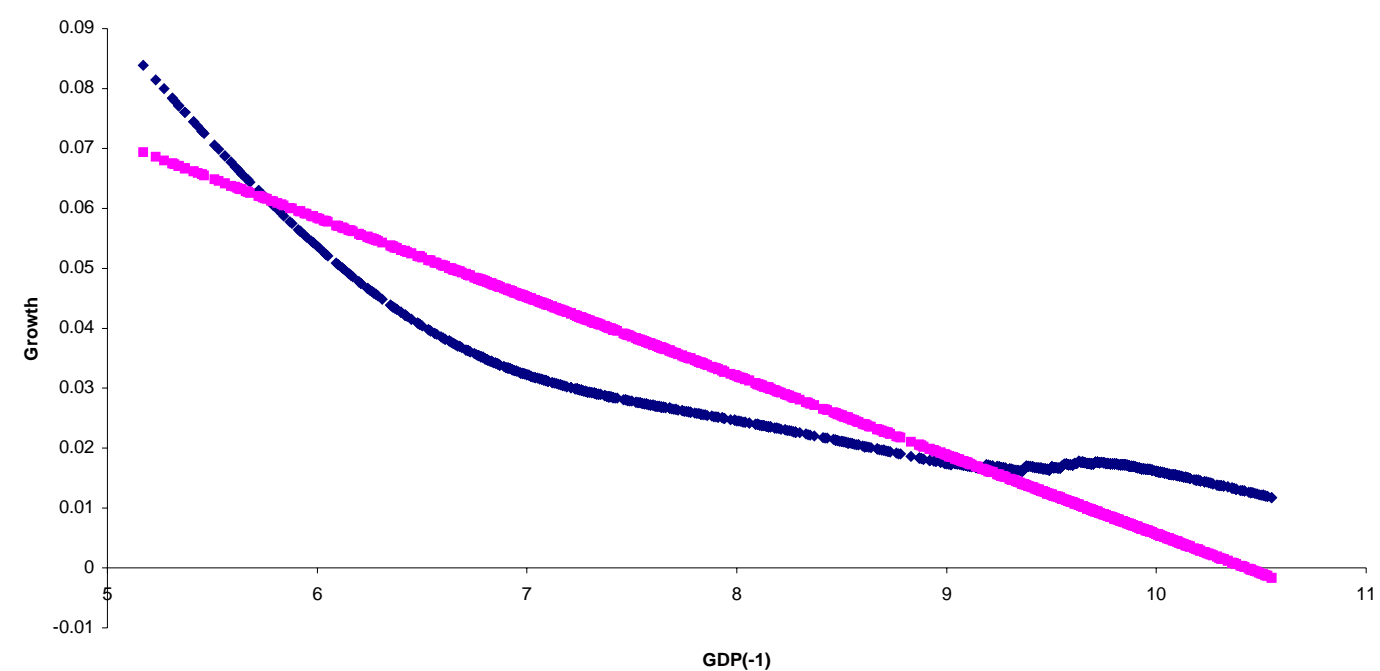

Figure 1. GDP growth and initial GDP

Figure 1 demonstrates the relationship between per capita growth and initial income is clearly non-linear. This is consistent with recent empirical evidence (see Durlauf and Johnson, 1995; Liu and Stengos, 1999; Pack and Page, 1994; Quah, 1996) on convergence. The curvature of the graph implies that, on average, high-income countries do not necessarily get lower growth rates, but they can rather increase their growth rates slightly or keep them steady.

Figure 2 shows the estimate of the non-parametric component for FDI share. The horizontal axis shows the share of FDI in GDP and the vertical axis the growth rate of per capita income. 


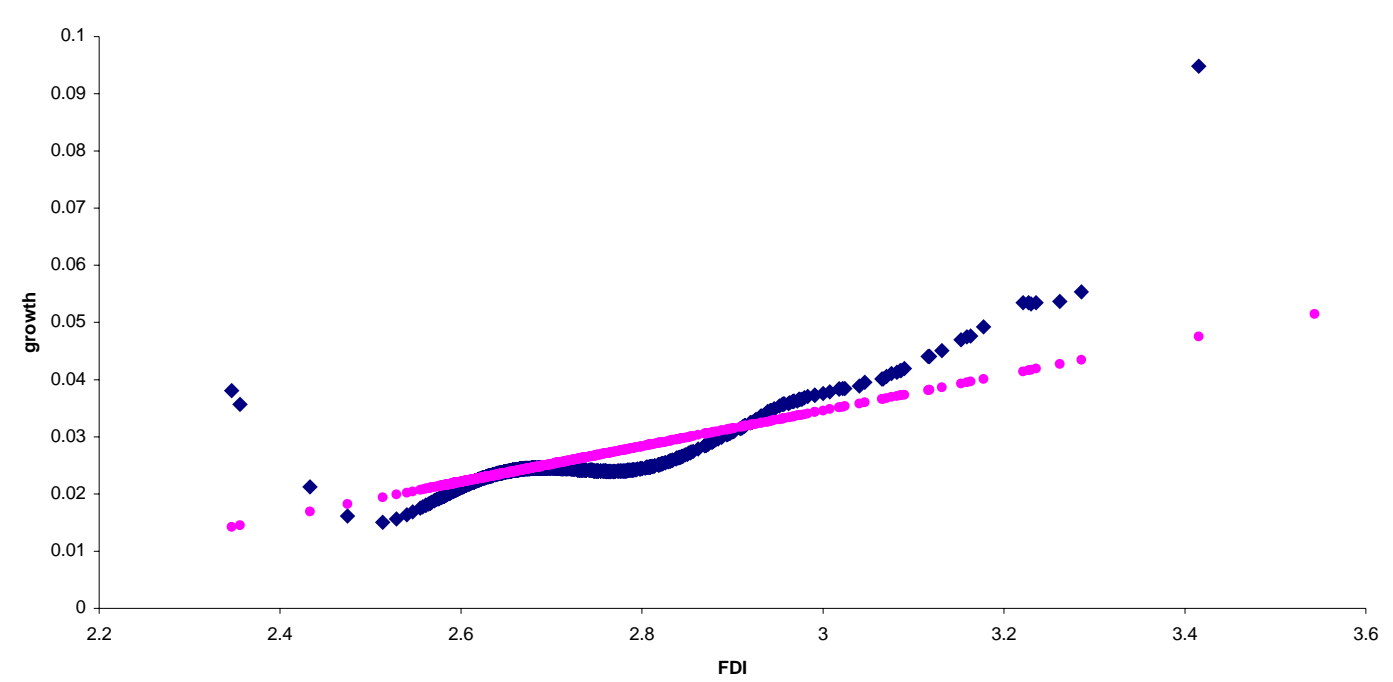

Figure 2. GDP growth and FDI

The relationship between economic growth and FDI appears to be nonlinear. In particular, there is a range of FDI share where we observe a negative effect whilst it appears that for countries with shares between approximately $1.9 \%$ and $4 \%$ the effect is negative. However on the whole the effect of FDI appears to be positive even though at differential rates for different groups of countries. Our results are consistent with prior macroeconomic studies that find an overall positive effect of FDI on growth and they also indicate the differential impact of FDI on different economies laid out earlier in the literature review. However, there is no study to date to use nonparametric techniques that allow for varying coefficients of FDI. Yet, a remarkable difference with these studies is that when we split the sample into OECD and nonOECD countries we didn't detect any significant differentiation in the pattern between the two.

Figure 3 shows the estimate of the non-parametric component of human capital. Previous studies suggesting a non-linear relationship to economic growth are 
confirmed: there are clearly thresholds in the effect of human capital. It is evident that for mean total years of schooling falling between 3 and 9.5, the effect is counterproductive, whilst at low and very high levels it is beneficial. This result is in line with Kalaitzidakis et al. (2001) where they found that for mean years of schooling between 0.9 and 4.4 the relationship is positive with a slight differentiation in what we find here, i.e., that the positive effect holds between approximately 1.5 and 3 mean years of schooling. The effect of human capital turns out positive again for above 10 years of schooling. To check the validity of the partial linear specification of the semiparametric formulation of the model we also allowed for interaction terms between human capital and FDI to enter the linear part of the model. However, this term was never significant in any of the specifications that we tried, in agreement with the separable structure of the model. This result reinforces the finding that the shape of the total human capital effect as depicted in figure 3 has not changed from that of the earlier literature through the introduction of FDI. In this regard FDI and human capital appear to be independent of each other in their influence of growth.

The analysis above is based on a panel of annual observations. To check the robustness of our results we also estimated the model using 5-year averages. The model estimated without the time trend produces results of the parametric part that are now numerically different but comparable to the ones we have obtained with the annual data, but the overall shapes of the effects of FDI, initial GDP per capita and human capital are virtually, with the nonlinear effects being preserved ${ }^{13}$. The results are available from the authors and are not reported to conserve space.

\footnotetext{
${ }^{13}$ These shapes were robust to also using lagged values to account for possible endogeneity.
} 


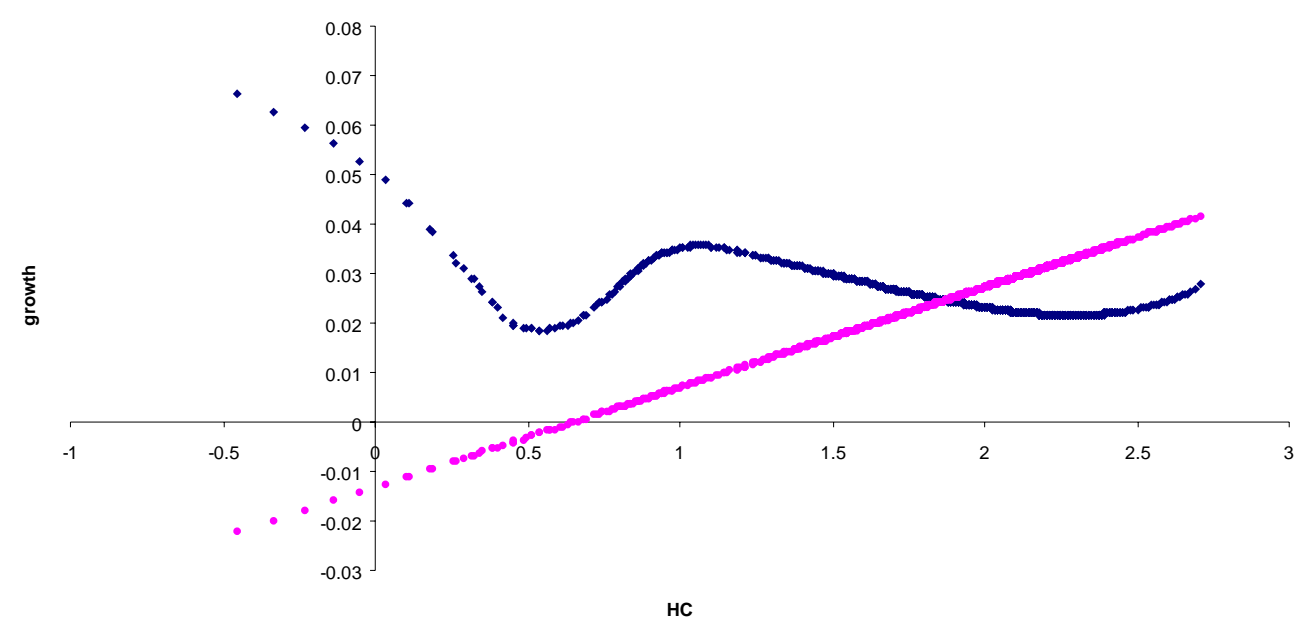

Figure 3. GDP growth and human capital (total mean years of schooling)

Overall, the evidence suggests that nonlinearities and jumps are quite significant in the analysis of FDI. The nonlinearity emerging in the relationship indicates that the way FDI affects growth differs across countries. The relationship appears to be complex and the impact varies according to a country's level of FDI. Following the spirit of cross-sountry regression literature (Durlauf and Johnson, 1995; Masanjala and Papageorgiou, 2004 and Kourtellos, 2003) parameter heterogeneity may exist in the sense that the effect of a change in a particular variable is not the same. Different coefficient estimates appear per country for the effect of initial income and human capital on growth and so does FDI too. In other words, there exists a different FDIgrowth nexus in different countries. FDI may be directed to different industries and activities in different countries and hence, the different characteristics of these may be responsible for the different coefficient estimates that emanates in the analysis. Even in the case of same sectors/industries, their productivities might be quite different based on a bundle of economy-specific conditions and institutional framework. 
Finally, one could think of nonlinearities as a simple reflection of countries differences in their timing in the transition path to the steady state (Galor, 2005).

\section{CONCLUSIONS}

In this paper we study the influence of FDI on the process of economic growth among a wide set of OECD and non-OECD countries by allowing the impact to differ both across each country and also across each time period. We apply non-parametric techniques taking into account the previously documented nonlinear effects of initial income and human capital on economic growth. Furthermore, we verify that initial income and human capital have a nonlinear effect on economic growth as suggested earlier in the literature even in the presence of foreign investments. Also, the results confront the majority of previous studies suggesting positive FDI effects conditioning in human capital and accord to the two recent studies that doubt this connection. Our paper parallels the widely discussed issue of non-linearities in convergence.

For our purposes, we collected data from the WDI of the World Bank, UNCTAD and the Vikram and Dhareshwar (1993) for twenty-five OECD and twenty nonOECD countries over the period 1970-2004. The countries were selected based on their availability of human capital data. In general, our findings support the hypothesis of non-linear effects of human capital and FDI on economic growth. Hence, we confirm here that there exist threshold levels of human capital and FDI and the growth experience of a country may well differ according to which side of the threshold it finds itself in.

The evidence may be of particular policy interest and it suggests that the FDIgrowth nexus is a complex one. In particular, it pinpoints the need for a country- 
specific targeted FDI policy design within each country rather than applying general rules related to tax incentives, import duty exceptions and other measures favoring FDI implemented elsewhere successfully. 


\section{REFERENCES}

Aitken, B. and A. Harrison (1999). Do Domestic Firms Benefit from Direct Foreign Investment? Evidence from Venezuela, American Economic Review, Vol. 89, pp. 605-618.

Alfaro, L., Areendam, Ch., Kelemli-Ozcan S. and S. Selim (2003). FDI and economic growth: the role of financial markets, Journal of International Economics, 61(1), 512533.

Azariadis C and A. Drazen (1990). Threshold externalities in economic development. Quarterly Journal of Economics 105: 501-526.

Balasubramanyam, V.N., M. Salisu and D. Sapsford (1996). Foreign Direct Investment and Growth in EP and Is Countries, The Economic Journal, 106: 92-105

Barro, R.J. (1991). Economic growth in a cross section of countries, Quarterly Journal of Economics, 106. 407-433.

Barro, R.J. (1998). Human Capital and Growth in Cross-Country Regressions (manuscript), Harvard University.

Barro, R.J. and J.W. Lee (2001). International data on educational attainment: updates and implications. CID Working Paper, No. 42.

Barro R and X. Sala-i-Martin (1995). Economic Growth. McGraw-Hill: New York.

Bende-Nabende, A. and J.L. Ford (1998) FDI, policy adjustments and endogenous growth: multiplier effects from a small dynamic model for Taiwan, 1959-1995, World Development, 26(7), 1315-30

Bengoa, M. and Sanchez-Robles, B. (2003). Foreign direct investment, economic freedom and growth: new evidence from Latin America, European Journal of Political Economy, 19(3), 529-45.

Benhabib, J, and M. Spiegel, (1994). The role of human capital ineconomic development: evidence from aggregate cross-country data, Journal of Monetary Economics, 34, 143-174.

Bils, M. and P.J. Klenow, (2000). Does schooling cause growth? American Economic Review, 90, 1160-1183.

Blomström, M. (1986). Foreign Investment and Productive Efficiency: The Case of Mexico, Economics, 15, pp. 97-110.

Blomström, M., Lipsey, R. and M. Zejan (1992). What explains developing country growth? NBER Working Paper, n. 4132. Cambridge, Mass.

Blomström, M., A. Kokko and M. Zejan (1994). Host Country Competition and Technology Transfer by Multinationals, Weltwirtschaftliches Archiv, 130, 521-533. 
Borensztein, E.R, Gregorio, J. and J-W Lee. (1998). How does foreign direct investment affect economic growth? Journal of International-Economics, 45(1), 11535 .

Carcovic M. and R. Levine (2002). Does foreign direct investment accelerate economic growth?, Department of Business Finance, University of Minessota, Working Paper Series. Paper also available at www.worldbank.org/research/conferences/financial_globalization/fdi.pdf

De Mello, L. (1999). Foreign Direct Investment led growth: Evidence from time series and panel data, Oxford Economic Papers 51, pp. 133-151.

Durham, J. B. (2004). Absorptive capacity and the effects of foreign direct investment and foreign portfolio investment on economic growth. European Economic Review, 48, 285-306.

Durlauf SN and P. Johnson (1995). Multiple regimes and cross country growth behavior. Journal of Applied Econometrics, 10: 365-384.

Durlauf SN, Kourtellos, A. and A. Minkin (2001). The local Solow growth model, European Economic Review, 45: 928-940.

Fan, J., Hardle, W. and E. Mammen (1998). Direct estimation of low dimensional components in additive models, Annals of Statistics, 26, 943-971.

Fan, Y. and Q. Li (2003). A new kernel-based method for estimating additive partially linear models, Statistica Sinica, 13, 739-762.

Fan, Y. and Q. Li (1996). Consistent model specification tests: omitted variables, parametric and semiparanetric functional forms, Econometrica, 64, 865-890.

Findlay, R. (1978). Relative backwardness, Direct Foreign Investment, and the transfer of technology: A simple dynamic model, Quarterly Journal of Economics, 92, pp. 1-16.

Fry, Maxwell J. (1992). Foreign Direct Investment in a macroeconomic framework: finance, efficiency, incentives and distortions', PRE Working Paper, Washington, DC: The World Bank.

Haddad, M. and A. Harrison (1993). Are there positive spillovers from direct foreign investment? Evidence from panel data for Morocco, Journal of Development Economics, 42, pp. 51-74.

Islam, N. (1995). Growth Empirics: A panel data approach, Quarterly Journal of Ecpnomics, 10, 1127-1170.

Kalaitzidakis, P., Mammumeas, T, Savvides, A. and T. Stengos (2001). Measures of human capital and non-linearities in economic growth, Journal of Economic Growth, $6,229-254$. 
Kathuria, V. (2001). Foreign firms, technology transfer and knowledge spillovers to Indian manufacturing firms: A stochastic frontier analysis, Applied Economics, 33, pp. 625-642.

Kokko, A. (1994). Technology, market characteristics, and spillovers, Journal of Development Economics, 43, pp. 279-293.

Kokko, A., R. Tansini and M. Zejan (1996). Local technological capability and spillovers from FDI in the Uruguayan manufacturing sector, Journal of Development Studies, 34, pp. 602-611.

Kottaridi, C. (2005). The 'core-periphery'pattern of FDI-led growth and production structure in the EU, Applied Economics 37, 99-113.

Kourtellos A. (2003). Modeling parameter heterogeneity in cross-country growth regression models. Mimeo, Department of Economics, University of Cyprus.

Krueger A.B. and M. Lindahl (2001). Education for growth: why and for whom? Journal of Economic Literature 39: 1101-1136.

Kyriacou G.A. (1991). Level and growth effects of human capital. C.V. Starr Center Economic Research Reports, 91-26, New Yprk University.

Lau L.J., Jamison D.T. and F.F. Louat (1991). Education and productivity in developing countries: an aggregate production function approach. Working Paper No. 612, World Bank.

Li Q. and S. Wang (1998). A simple consistent bootstrap test for a parametric regression function. Journal of Econometrics, 87, 45-165.

Linton, O.B. and J.P. Nielsen (1995). A kernel method of estimating structural nonparametric regression based on marginal integration, Biometrica, 82, 93-100.

Liu Z. and T. Stengos, (1999). Non-linearities in cross-country growth regressions: a semiparametric approach, Journal of Applied Econometrics, 14, 527-538.

Mamuneas, T., Savvides, A. and T. Stengos, (2006). Economic development and the return to human capital: a smooth coefficient semiparametric approach, Journal of Applied Econometrics, 21, 111-132.

Mankiw, N., Romer, D. and D.N. Weil (1992). A controbution to the empirics of economic growth. Quarterly Journal of Economics, 107, 407-37.

Masanjala W.H. and C. Papageorgiou (2004). The Solow model with CES technology: nonlinearities and parameter heterogeneity Journal of Applied Econometrics 19, 171-201.

Pritchett L. (2001). Where has all the education gone? World Bank Economic Review 15: $367-391$. 
Sánchez-Robles, B. (1998)., Infrastructure investment and growth: Some empirical evidence, Contemporary Economic Policy, Vol. XVI, n.1, pp.98-109.

Vikram, N. and A. Dhareshwar (1993). A new database on physical capital stock: sources, methodology and results. Rivista de Analisis Economico, 8 (1), 37-59.

Vikram, N., Swanson, E. and A. Dubey (1995). A new database on human capital stock in developing and industrial countries: sources, methodology and results. Journal of Development Economics, 46, 379-401.

$\mathrm{Xu}$, B. (2000). Multinational enterprises, technology diffusion, and host country productivity growth, Journal of Development Economics, 62: 477-493.

Zhang, K. (2001). Does foreign direct investment promote growth? Evidence from East Asia and Latin America, Contemporary Economic Policy 19, 2, 175-85.

Zheng, J.X. (1996). A consistent test of functional form via nonparametric estimation techniques. Journal of Econometrics 75, 263-289. 


\section{APPENDIX}

\section{Sample Countries}

\begin{tabular}{|c|c|c|c|}
\hline OECD -Country & Region & $\begin{array}{c}\text { Non-OECD } \\
\text { Country }\end{array}$ & Region \\
\hline Belgium & EU & Brazil & Latin America \\
\hline Canada & Canada & Chile & Latin America \\
\hline Denmark & EU & China & Asia \\
\hline Finland & EU & Colombia & Latin America \\
\hline France & EU & Cote D'Ivoire & Africa \\
\hline Germany & EU & Egypt & \\
\hline Greece & EU & India & Asia \\
\hline Iceland & Other Europe & Indonesia & Asia \\
\hline Ireland & $\mathrm{EU}$ & Malaysia & Asia \\
\hline Italy & EU & Morocco & Africa \\
\hline Japan & Asia & Nigeria & Africa \\
\hline Korea, Rep & Asia & Pakistan & Asia \\
\hline Mexico & Latin America & Panama & Latin America \\
\hline Netherlands & EU & Paraguay & Latin America \\
\hline New Zealand & Oceania & Peru & Latin America \\
\hline Norway & Other Europe & Singapore & Asia \\
\hline Portugal & $\mathrm{EU}$ & Thailand & Asia \\
\hline Spain & EU & Tunisia & Africa \\
\hline Sweden & EU & & \\
\hline Switzerland & Other Europe & & \\
\hline Turkey & Asia & & \\
\hline United Kingdom & EU & & \\
\hline United States & America & & \\
\hline
\end{tabular}

